\title{
DETHYMICIN, A NOVEL IMMUNOSUPPRESSANT ISOLATED FROM AN Amycolatopsis \\ FERMENTATION, ISOLATION, PHYSICO-CHEMICAL PROPERTIES AND BIOLOGICAL ACTIVITIES
}

\author{
Mitsuhiro Ueno, Masatomi Iijima, Toru Masuda, Naoko Kinoshita ${ }^{\dagger}$, \\ Hrronobu Iinuma ${ }^{\dagger}$, Hiroshi Naganawa ${ }^{\dagger}$, Masa Hamada ${ }^{\dagger}$, \\ MASAaKI ISHIZUKA* and TOMIO TAKEUCHI \\ Institute for Chemotheraphy, Microbial Chemistry Research Foundation, \\ 18-24 Aza-Motono, Miyamoto, Numazu-shi, Shizuoka 410-03, Japan \\ ${ }^{\dagger}$ Institute of Microbial Chemistry, Microbial Chemistry Research Foundation, \\ 3-14-23 Kamiosaki, Shinagawa-ku, Tokyo 141, Japan
}

(Received for publication June 29, 1992)

\begin{abstract}
In the course of screening for immunomodulators inhibiting the mixed lymphocyte culture reaction (MLCR), we found a novel immunosuppressant, dethymicin in mycelium of Amycolatopsis mediterranei MI710-51F6. From physico-chemical properties and biological activity it is different from immunosuppressants produced by microorganisms such as cyclosporins, FK506 and rapamycin. It inhibited immune responses in vitro and in vivo, and prolonged skin allograft in rats.
\end{abstract}

In the course of screening for immunomodulators exhibiting immunosuppressive effect on mixed lymphocyte culture reaction (MLCR), we found a new immunosuppressant, dethymicin, in cultured mycelium of Amycolatopsis mediterranei MI710-51F6. In this paper, we report the taxonomy, fermentation, isolation and purification, physico-chemical properties and biological activities of dethymicin.

\section{Taxonomy}

The producing microorganism, strain MI710-51F6, was isolated from a soil sample collected in Hayama-machi, Kanagawa Prefecture, Japan. The cultural characteristics ${ }^{1)}$ of strain MI710-51F6 are shown in Table 1. Strain MI710-51F6 has branched vegetative hyphae with a slight tendency to zig-zagshaped, and aerial hyphae in the form of straight or wavy. Partial fragmentation of the vegetative and aerial hyphae was observed. The aerial hyphae bore chains of ellipsoid to oblong spores. The spores are 0.3 to 0.5 by 0.9 to $1.4 \mu \mathrm{m}$ in size with smooth surfaces. No sporangia, motile spores or synnemata were observed. This strain is not acid-fast.

Physiological characteristics ${ }^{2,3)}$ of strain MI710-51F6 are shown in Table 2.

The whole cell hydrolysate contained meso-2,6-diaminopimelic acids, arabinose and galactose, hence the cell wall composition is type IV and the whole-cell sugar pattern is type $\mathrm{A}^{4)}$. The isoprenoid quinones extracted from the cells were identified as MK-9 $\left(\mathrm{H}_{4}\right)$ and MK-9 $\left(\mathrm{H}_{2}\right)$ by EI-MS. Since phosphatidylethanolamine but no phosphatidyl choline and undescribed phospholipids containing glucosamine in the cell component were found by TLC analysis ${ }^{5}$, phospholipids were determined to be type PII. Fatty acids in methanolysates of the whole organism were analyzed by gas chromatography ${ }^{6)}$ and found major amounts of iso-branched 14-methylpentadecanoic acid (i-16), anteiso-branched 14-methyl- 
Table 1. Cultural characteristics of strain MI710-51F6.

\begin{tabular}{|c|c|c|c|c|}
\hline Medium & Growth & Aerial mycelium & Substrate mycelium & $\begin{array}{l}\text { Soluble } \\
\text { pigments }\end{array}$ \\
\hline Sucrose - nitrate agar & Good & Shell (3ca) & Light mellon yellow (3ea) & None \\
\hline Glucose - asparagine agar & Good & Shell tint $\sim$ Shell $(3 \mathrm{ba} \sim 3 \mathrm{ca})$ & Bamboo $(2 \mathrm{gc})$ & None \\
\hline $\begin{array}{l}\text { Glycerol - asparagine agar } \\
\text { (ISP-5) }\end{array}$ & Good & $\begin{array}{l}\text { Light ivory } \sim \text { Light melon } \\
\text { yellow }(2 \mathrm{ca} \sim 3 \mathrm{ea})\end{array}$ & Light melon yellow (3ea) & None \\
\hline $\begin{array}{l}\text { Inorganic salts - starch agar } \\
\text { (ISP-4) }\end{array}$ & Good & Light ivory (2ca) & Bamboo $(2 \mathrm{gc})$ & None \\
\hline Tyrosine agar (ISP-7) & Good & $\begin{array}{l}\text { Shell } \sim \text { Light melon yellow } \\
\quad(3 \mathrm{ca} \sim 3 \mathrm{ea})\end{array}$ & $\begin{array}{l}\text { Honey gold } \sim \text { Light melon } \\
\text { yellow } \sim \text { Amber } \\
\quad(2 \mathrm{ic} \sim 3 \mathrm{ea} \sim 3 \mathrm{pc})\end{array}$ & None \\
\hline Nutrient agar & Poor & White & Honey gold (2ic) & None \\
\hline $\begin{array}{l}\text { Yeast extract - malt extract } \\
\text { agar (ISP-2) }\end{array}$ & Good & Shell pink (5ba) & Light $\tan (3 \mathrm{gc})$ & None \\
\hline Oatmeal agar (1SP-3) & Good & White & Bamboo $(2 \mathrm{gc})$ & None \\
\hline Glycerol - nitrate agar & Good & $\begin{array}{l}\text { Shell } \sim \text { Light melon yellow } \\
\quad(3 \mathrm{ca} \sim 3 \text { ea })\end{array}$ & $\begin{array}{l}\text { Light melon yellow } \sim \text { Light } \\
\quad \text { olive }\left(3 \mathrm{ea} \sim 1 \frac{1}{2} \mathrm{ie}\right)\end{array}$ & None \\
\hline Starch agar & Good & Shell $(3 \mathrm{ca})$ & Honey gold (2ic) & None \\
\hline
\end{tabular}

Observation after incubation at $30^{\circ} \mathrm{C}$ for 21 days.

Color names and numbers from Color Harmony Manual, Container Corporation of America.

Table 2. Physiological characteristics of strain MI710-51F6.

\begin{tabular}{|c|c|c|c|}
\hline $\begin{array}{l}\text { Temperature range for growth }\left({ }^{\circ} \mathrm{C}\right) \\
\text { Optimum temperature }\left({ }^{\circ} \mathrm{C}\right) \\
\text { Formation of melanoid pigment } \\
\text { Liquefaction of gelatin } \\
\text { Coagulation of milk } \\
\text { Peptonization of milk } \\
\text { Hydrolysis of starch } \\
\text { Reduction of nitrate } \\
\text { Decomposition of } \\
\text { hypoxanthine } \\
\text { xanthine } \\
\text { Growth on } 5 \% \mathrm{NaCl}\end{array}$ & $\begin{array}{l}20 \sim 37 \\
27 \sim 30 \\
\text { Negative } \\
\text { Positive } \\
\text { Negative } \\
\text { Positive } \\
\text { Weak } \\
\text { Positive } \\
\text { Positive } \\
\text { Negative } \\
+\end{array}$ & $\begin{array}{l}\text { Acid produced from } \\
\text { cellobiose } \\
\text { meso-erythritol } \\
\text { D-glucose } \\
\text { raffinose } \\
\text { Utilization of } \\
\text { L-arabinose } \\
\text { D-xylose } \\
\text { D-glucose } \\
\text { D-fructose } \\
\text { rhamnose } \\
\text { sucrose } \\
\text { raffinose } \\
\text { inositol } \\
\text { D-mannitol }\end{array}$ & $\begin{array}{c}\text { Positive } \\
\text { Positive } \\
\text { Positive } \\
\text { Positive } \\
+ \\
+ \\
+ \\
+ \\
+ \\
+ \\
+ \\
+ \\
+\end{array}$ \\
\hline
\end{tabular}

+ : Growth.

hexadecanoic acid (a-17) and iso-branched 13-methyltetradecanoic acid (i-15) and no mycolic acid.

Accordingly, strain MI710-51F6 is considered to be in the genus Amycolatopsis ${ }^{7)}$. Among the genus Amycolatopsis, Amycolatopsis mediterranei and Amycolatopsis orientalis are similar to strain MI710-51F6. As shown in Table 3, strain MI710-51F6 is different from A. orientalis in fatty acids composition, coagulation of milk, decomposition of xanthine, acid production from raffinose and utilization of sucrose and raffinose. Strain MI710-51F6 is closely related to A. mediterranei except for acid production from mesoerythritol and utillization of raffinose. DNA relatedness among strain MI710-51F6, A. mediterranei IMC A-0162 (ISP 5501) and $A$. orientalis IMC A-0161 (ISP 5040) was examined by a Southern blot technique. Strain MI710-51F6 showed high homology with A. mediterranei qualitatively. Therefore, it was designated as A. mediterranei MI710-51F6. 
Table 3. Comparison of strain MI710-51F6 with type strains of Amycolatopsis mediterranei and Amycolatopsis orientalis.

\begin{tabular}{|c|c|c|c|}
\hline Characteristics & MI710-51F6 & $\begin{array}{l}\text { A. mediterranei } \\
\text { IMC A-0162 } \\
\text { (ISP 5501) }\end{array}$ & $\begin{array}{l}\text { A. orientalis } \\
\text { IMC A-0161 } \\
\text { (ISP 5040) }\end{array}$ \\
\hline Fatty acids ${ }^{a}$ & $\underline{i-16^{\mathrm{b}}}, a-17, i-15$ & $i-16^{\mathrm{b}}, a-17, i-15,16: 1$ & $i-15^{\mathrm{b}}, i-16,16: 0,17: 0, a-17$ \\
\hline $\begin{array}{l}\text { Color of aerial } \\
\text { mycelium }^{c}\end{array}$ & $\begin{array}{l}\text { White to pale yellow } \\
\text { orange }\end{array}$ & $\begin{array}{l}\text { None to white to pale } \\
\text { orange }\end{array}$ & White \\
\hline $\begin{array}{l}\text { Color of substrate } \\
\text { mycelium }^{c}\end{array}$ & $\begin{array}{l}\text { Pale yellow to pale yellow } \\
\text { orange }\end{array}$ & $\begin{array}{l}\text { Dull yellow orange to light } \\
\text { yellowish orange }\end{array}$ & $\begin{array}{l}\text { Pale yellow to pale yellow } \\
\text { orange }\end{array}$ \\
\hline Coagulation of milk & Negative & Negative & Positive \\
\hline $\begin{array}{l}\text { Decomposition of } \\
\text { xanthine }\end{array}$ & Negative & Negative & Positive \\
\hline \multicolumn{4}{|l|}{ Acid from } \\
\hline meso-erythritol & Positive & Negative & Positive \\
\hline raffinose & Positive & Positive & Negative \\
\hline \multicolumn{4}{|l|}{ Utilization of } \\
\hline raffinose & + & - & - \\
\hline sucrose & + & + & - \\
\hline
\end{tabular}

a $i$-15, iso-branched 13-methyltetradecanoic acid; $a$-17, anteiso-branched 14-methylhexadecanoic acid; 16:0, saturated hexadecanoic acid.

b Under line, main component.

c Color names from Guide to Color Standard, Nihon Shikisai Co., Ltd.

+ Growth.

Table 4. Time course of dethymicin production.

\begin{tabular}{lllccccc}
\hline Incubation time (hours) & 0 & 24 & 40 & 48 & 64 & 90 \\
\hline $\mathrm{pH}$ & & 7.0 & 8.2 & 7.7 & 7.2 & 7.1 & 7.0 \\
Potency $(\mu \mathrm{g} / \mathrm{ml})^{\mathrm{a}}$ & sup & - & - & - & 5 & 4 & 4 \\
PMV $(\mathrm{ml} / 10 \mathrm{ml})^{\mathrm{b}}$ & myc & - & - & 10 & 51 & 227 & 225 \\
\hline
\end{tabular}

a Determined by HPLC using a CAPCELL PAK $5 \mathrm{C}_{18}\left(\mathrm{MeOH}-50 \mathrm{~mm} \mathrm{NH}_{4} \mathrm{OAc}-\mathrm{CH}_{3} \mathrm{CN}(65: 30: 5), 1 \mathrm{ml} / \mathrm{minute}\right.$, UV $235 \mathrm{~nm}$ ).

b Packed mycelium volume.

\section{Fermentation}

The medium contained glycerol $2.0 \%$, dextrin $2.0 \%$, Bacto soytone (Difco) $1.0 \%$, yeast extract (Daigo Eiyo) $0.3 \%,\left(\mathrm{NH}_{4}\right)_{2} \mathrm{SO}_{4} 0.2 \%, \mathrm{CaCO}_{3} 0.2 \%$, one drop of silicone oil (Shinetsu Kagaku) was employed for seed culture and production. The strain MI710-51F6 on an agar slant was inoculated into a $500-\mathrm{ml}$ Erlenmeyer flask containing $110 \mathrm{ml}$ of the medium and cultured at $30^{\circ} \mathrm{C}$ for 3 days on a rotary shaker $(180 \mathrm{rpm})$. Two $\mathrm{ml}$ of this seed culture was inoculated into $110 \mathrm{ml}$ of the medium in $500-\mathrm{ml}$ Erlenmeyer flasks and cultured at $28^{\circ} \mathrm{C}$ for 4 days on a rotary shaker $(180 \mathrm{rpm})$ for production. Typical fermentation profiles for production of dethymicin in cultured broth and mycelium are shown in Table 4. The amount of dethymicin was determined by HPLC using a CAPCELL PAK $5 \mathrm{C}_{18}$ column (Shiseido) with a mobile phase of $\mathrm{MeOH}-50 \mathrm{~mm} \mathrm{NH} \mathrm{N}_{4} \mathrm{OAc}-\mathrm{CH}_{3} \mathrm{CN}(65: 30: 5)$. As shown in Table 4, although dethymicin was found in both cultured broth and mycelium, the active principle was in the mycelium. After 64 hours cultivation, dethymicin was accumulated in broth and mycelium, $4 \mu \mathrm{g} / \mathrm{ml}$ and $227 \mu \mathrm{g} / \mathrm{ml}$, respectively. Therefore, dethymicin was isolated from the cultured mycelium of MI710-51F6. 
Isolation and Purification

The procedure for isolation and purification of dethymicin is shown in Fig. 1. The cultured broth (10 liters) was centrifuged and the mycelium was harvested. The mycelium was extracted twice with five volumes of $\mathrm{MeOH}$ per wet weight of mycelium. The extract was concentrated under reduced pressure to give an aqueous solution. The aqueous solution was added to the same volume of $\mathrm{CH}_{3} \mathrm{CN}$ and was kept at $10^{\circ} \mathrm{C}$ to deposit precipitations. The precipitates collected by filtration was dissolved in a small amount of $\mathrm{MeOH}$. To the methanolic solution, acetone was added to give a white precipitates. The precipitates collected by filtration was dissolved in $\mathrm{MeOH}$ and then loaded onto a Sephadex LH-20 column $(4.6 \times 65 \mathrm{~cm})$. The activity was eluted with $\mathrm{MeOH}$ and concentrated under reduced pressure. The crude material $(700 \mathrm{mg})$ was subjected to centrifugal partition chromatography (CPC, Sanki Engineering) previously equilibrated with the lower layer of $\mathrm{CHCl}_{3}-\mathrm{MeOH}$-water $(2: 2: 1)$ at $25^{\circ} \mathrm{C}, 400 \mathrm{rpm}$. The activity was eluted with the upper layer of $\mathrm{CHCl}_{3}-\mathrm{MeOH}$-water $(2: 2: 1)$ in the ascending mode and concentrated under reduced pressure. The resulting residue was applied to a reverse phase HPLC column (CAPCELL PAK C $1820 \times 250 \mathrm{~mm}$, flow rate $5 \mathrm{ml} / \mathrm{minute}$ ) and eluted with a mobile phase of $\mathrm{MeOH}-50 \mathrm{mM} \mathrm{NH}_{4} \mathrm{OAc}-\mathrm{CH}_{3} \mathrm{CN}(65: 30: 5)$. The active fractions were concentrated under reduced pressure and then loaded onto Sephadex LH-20 column. The activity was eluted with $\mathrm{MeOH}$ and concentrated under reduced pressure to give pure dethymicin as a white powder $(250 \mathrm{mg})$.

\section{Physico-chemical Properties}

Physico-chemical properties of dethymicin are summarized in Table 5. It is soluble in $\mathrm{MeOH}$, EtOH, DMSO, $n-\mathrm{BuOH}$ and slightly soluble in water, acetone, acetonitrile, diethyl ether, hexane. Color reactions are: positive in vanillin sulfate and negative in ninhydrin, Dragendorff, Rydon-Smith, 2,4-DNP and bromocresol green. The molecular weight and formula were determined to be $\mathrm{C}_{71} \mathrm{H}_{126} \mathrm{~N}_{2} \mathrm{O}_{21}$ (MW 1,342) by HRFAB-MS and elemental analysis.

\section{Biological Activities}

\section{Mixed Lymphocytes Culture Reaction (MLCR)}

Spleen cells (nylon wool-passed) taken from Fisher F344 rats as the responder were mixed with spleen cells taken from WKY rats as the stimulator which had been previously incubated with $50 \mu \mathrm{g} / \mathrm{ml}$ of mitomycin $\mathrm{C}$ at $37^{\circ} \mathrm{C}$ for 20 minutes. The mixed cells were cultured with or without drugs in medium 
Table 5. Physico-chemical properties of dethymicin.

\begin{tabular}{|c|c|}
\hline Appearance & Colorless $\sim$ white powder \\
\hline MP & $137 \sim 139^{\circ} \mathrm{C}$ \\
\hline Molecular formula & $\mathrm{C}_{71} \mathrm{H}_{126} \mathrm{O}_{21} \mathrm{~N}_{2}$ (EF-FAB (positive)) \\
\hline Mass spectrum & $1,343(\mathrm{M}+1, \mathrm{FAB}-\mathrm{MS})$ \\
\hline Optical rotation & {$[\alpha]_{\mathrm{D}}^{26}-33.3^{\circ}(c 0.733, \mathrm{MeOH})$} \\
\hline \multicolumn{2}{|l|}{ Elemental analysis $(\%)$} \\
\hline Calcd for $\mathrm{C}_{71} \mathrm{H}_{126} \mathrm{O}_{21} \mathrm{~N}_{2} \cdot 4 \mathrm{H}_{2} \mathrm{O}$ : & C 60.23, H 9.54, O 28.25, N 1.98 \\
\hline Found: & C $60.33, \mathrm{H} 9.52, \mathrm{O} 27.48, \mathrm{~N} 2.44$ \\
\hline UV spectrum $\lambda_{\max }^{\mathrm{MeOH}} \mathrm{nm}\left(\mathrm{E}_{1 \mathrm{~cm}}^{1 \%}\right)$ & $276(136), 234(137)$ \\
\hline IR spectrum $\nu_{\max }^{\mathrm{KBr}} \mathrm{cm}^{-1}$ : & $3370,2970,2940,1660,1600,1460,1380,1070$ \\
\hline TLC $^{a} \quad$ Rf value $^{b}$ & 0.57 \\
\hline Rf value ${ }^{c}$ & 0.08 \\
\hline
\end{tabular}

Table 6. Inhibitory effect of dethymicin on MLCR.

\begin{tabular}{ccc}
\hline $\begin{array}{c}\text { Dethymicin } \\
(\mu \mathrm{g} / \mathrm{ml})\end{array}$ & $\begin{array}{c}\text { Mean } \pm \text { S.D. } \\
\left(10^{3} \mathrm{cpm}\right)\end{array}$ & $\begin{array}{c}\text { Inhibition } \\
(\%)\end{array}$ \\
\hline 12.5 & $1.9 \pm 0.2$ & $78.3^{* * *}$ \\
3.13 & $3.1 \pm 1.0$ & $64.0^{* * *}$ \\
0.78 & $5.4 \pm 0.2$ & $36.1^{* * *}$ \\
0.20 & $6.8 \pm 1.9$ & 19.9 \\
None & $8.5 \pm 0.3$ & 0 \\
\hline
\end{tabular}

*** $P<0.001$ as compared with medium control.

containing $10 \%$ fetal calf serum (FCS) at $37^{\circ} \mathrm{C}$ for 5 days in $5 \% \mathrm{CO}_{2}$ in air and $\left[{ }^{3} \mathrm{H}\right]$ thymidine was added 16 hours before assay. MLCR was determined by measuring the incorporation of $\left[{ }^{3} \mathrm{H}\right]$ thymidine into the cultured cells. Dethymicin dissolved in $\mathrm{MeOH}$ was diluted with RPMII640 and added to cultures. Triplicate determinations were made. As shown in Table 6 , dethymicin inhibited MLCR in a dose dependent manner at 0.78 to $12.5 \mu \mathrm{g} / \mathrm{ml}$ and the $\mathrm{IC}_{50}$ was $1.5 \mu \mathrm{g} / \mathrm{ml}$.
Table 7. Inhibitory effect of dethymicin on lectin induced proliferation of splenic lymphocytes.

\begin{tabular}{lcrc}
\hline & $\begin{array}{c}\text { Dethymicin } \\
(\mu \mathrm{g} / \mathrm{ml})\end{array}$ & $\begin{array}{r}\text { Mean } \pm \text { S.D. } \\
\left(\times 10^{2} \mathrm{cpm}\right)\end{array}$ & $\begin{array}{c}\text { Inhibition } \\
(\%)\end{array}$ \\
\hline None & - & $14.6 \pm 1.8$ & \\
& 100 & $1.7 \pm 0.4$ & $88^{* * *}$ \\
& 25 & $6.3 \pm 0.6$ & $57^{* * *}$ \\
Con $\mathrm{A}^{\mathrm{a}}$ & 6.25 & $10.0 \pm 0.4$ & 31 \\
& - & $170.7 \pm 11.7$ & \\
& 100 & $27.0 \pm 2.5$ & $84^{* * *}$ \\
& 25 & $74.0 \pm 3.8$ & $57^{* * *}$ \\
& 6.25 & $64.4 \pm 27.1$ & $62^{* * *}$ \\
& 1.56 & $58.0 \pm 16.3$ & $66^{* * *}$ \\
& 0.39 & $136.8 \pm 22.5$ & $20^{*}$ \\
LPS $^{b}$ & 0.10 & $167.2 \pm 9.4$ & 2 \\
& - & $111.7 \pm 4.8$ & \\
& 100 & $2.5 \pm 0.6$ & $98^{* * *}$ \\
& 25 & $41.4 \pm 2.1$ & $63^{* * *}$ \\
& 6.25 & $79.7 \pm 11.4$ & $29^{* *}$ \\
& 1.56 & $103.8 \pm 1.2$ & 7 \\
\hline
\end{tabular}

a Concanavalin A (Con A) in $0.5 \mu \mathrm{g} / \mathrm{ml}$.

b Lipopolysaccharide (LPS) in $2 \mu \mathrm{g} / \mathrm{ml}$.

*** $\quad P<0.001$ as compared with medium control.

** $P<0.01$.

* $\quad P<0.05$.

\section{Lectin-induced Proliferation of Murine Splenic Lymphocytes}

Spleen cells $\left(1 \times 10^{6} / \mathrm{ml}\right)$ taken from $\mathrm{CDF}_{1}$ mice were cultured in flat-bottom microplates at $37^{\circ} \mathrm{C}$ for 48 hours with dethymicin, and with or without lectin $(0.5 \mu \mathrm{g} / \mathrm{ml}$ of Con A or $2 \mu \mathrm{g} / \mathrm{ml}$ of LPS) in $0.2 \mathrm{ml}$ of RPMI1640 medium supplemented with $1 \%$ FCS. They were cultured in a fully humidified atmosphere of $5 \% \mathrm{CO}_{2}$ in air. Triplicate cultures were made in each test. Sixteen hours before assay, $0.1 \mu \mathrm{Ci} /$ well of $\left[{ }^{3} \mathrm{H}\right]$ thymidine was added to each culture and the incorporation of $\left[{ }^{3} \mathrm{H}\right]$ thymidine into cells was determined. As shown in Table 7, dethymicin inhibited both lectin-induced blastgenesis and showed stronger inhibition on Con A-stimulated cells than LPS-stimulated. $\mathrm{IC}_{50}$ values were $0.95 \mu \mathrm{g} / \mathrm{ml}$ and $15.0 \mu \mathrm{g} / \mathrm{ml}$, respectively. 
Immune Responses to Sheep Red Blood Cells (SRBC) in Mice

Antibody formation: Female $\mathrm{CDF}_{1}$ mice (10 weeks old) were immunized on day 0 with $1 \times 10^{8}$ SRBC iv. Antibody formation was determined on day 4 by enumerating plaque forming cells (PFC) according to the method described previously ${ }^{8)}$. Drug was administrated ip daily from days 1 to 3 after immunization. Dethymicin in doses of 0.78 to $50 \mathrm{mg} / \mathrm{kg}$ did not suppress antibody formation.

Delayed-type hypersensitivity response $(\mathrm{DTH})$ : $\mathrm{CDF}_{1}$ mice were immunized iv with $1 \times 10^{5} \mathrm{SRBC}$. Four days later, $1 \times 10^{8} \mathrm{SRBC}$ was injected subcutaneous into the left hind footpad. Twenty four hours

Table 8. Suppressive effect of dethymicin on DTH response to $\mathrm{SRBC}$ in mice.

\begin{tabular}{cccc}
\hline $\begin{array}{c}\text { Dethymicin } \\
(\mathrm{mg} / \mathrm{kg})\end{array}$ & $n$ & $\begin{array}{c}\text { Increase of } \\
\text { footpad thickness } \\
(\times 0.1 \mathrm{~mm} \pm \text { S.D. })\end{array}$ & $\begin{array}{c}\text { Inhibition } \\
(\%)\end{array}$ \\
\hline None $^{\mathrm{b}}$ & 5 & $15.60 \pm 1.50$ & 0 \\
50 & 5 & $-0.10 \pm 0.00$ & $100.6^{* * *}$ \\
12.5 & 5 & $5.10 \pm 0.87$ & $67.3^{* *}$ \\
3.13 & 5 & $16.06 \pm 1.07$ & -6.4 \\
0.78 & 4 & $14.05 \pm 0.32$ & 9.9
\end{tabular}

a Dethymicin was dissolved in DMSO-Tween 80 saline $(9: 1: 90)$ and given ip daily from days 1 to 3 after immunization.

b Vehicle $(0.25 \mathrm{ml})$ was given ip as same schedule for drug.

*** $P<0.001$ as compared with vehicle group.

** $P<0.01$. after the elicitation, footpad thickness was measured with a caliper. Drug was injected ip daily for 3 days starting from 1 day after immunization. As

Table 9. Prolongation of skin allograft by dethymicin.

\begin{tabular}{cccl}
\hline $\begin{array}{c}\text { Dethymicin } \\
(\mathrm{mg} / \mathrm{kg})\end{array}$ & $n$ & $\begin{array}{c}\text { M.S.D. } \\
\text { (days } \pm \text { S.D. })\end{array}$ & $\begin{array}{l}\text { T/C } \\
(\%)\end{array}$ \\
\hline None $^{\mathrm{b}}$ & 11 & $10.27 \pm 2.28$ & 100.0 \\
20 & 8 & $16.38 \pm 5.29$ & $159.4^{* *}$ \\
5 & 8 & $13.38 \pm 1.19$ & $130.2^{*}$ \\
\hline
\end{tabular}

a Dethymicin was dissolved in DMSO-Tween $80-$ saline $(9: 1: 90)$ and given ip daily on days 1 to 9 after transplantation.

b Vehicle $(0.25 \mathrm{ml})$ was given ip as same schedule for drug.

${ }^{* *} P<0.01, * P<0.05$ as compared with vehicle group.

Table 10. Antimicrobial activity of dethymicin.

\begin{tabular}{|c|c|c|c|}
\hline Microorganisms & $\begin{array}{c}\mathrm{MIC} \\
(\mu \mathrm{g} / \mathrm{ml})\end{array}$ & Microorganisms & $\begin{array}{c}\text { MIC } \\
(\mu \mathrm{g} / \mathrm{mi})\end{array}$ \\
\hline Staphylococcus aureus FDA209P & $<0.78$ & Proteus vulgaris OX19 & $>100$ \\
\hline S. aureus Smith & 0.1 & P. mirabilis IFM OM-9 & $>100$ \\
\hline S. aureus MS9610 & 0.2 & Providencia rettgeri GN311 & $>100$ \\
\hline S. aureus No. 5 (MRSA) & 0.39 & P. rettgeri GN466 & $>100$ \\
\hline S. aureus No. 17 (MRSA) & 0.2 & Serratia marcescens & $>100$ \\
\hline Micrococcus luteus FDA16 & $<0.78$ & Pseudomonas aeruginosa A3 & $>100$ \\
\hline M. luteus IFO 3333 & $<0.78$ & $P$. aeruginosa $\mathrm{GN} 315$ & $>100$ \\
\hline M. luteus PCI 1001 & 1.56 & Klebsiella pneumoniae PCI 602 & $>100$ \\
\hline Bacillus anthracis & $<0.78$ & Mycobacterium smegmatis ATCC 607 & $>100$ \\
\hline B. subtilis NRRL B-558 & 3.12 & Candida tropicalis $\mathrm{F}-\mathrm{I}$ & $>100$ \\
\hline B. subtilis PCI 219 & $>100$ & C. pseudotropicalis $\mathrm{F}-2$ & $>100$ \\
\hline B. cereus ATCC 10702 & $<0.78$ & C. albicans 3147 & $>100$ \\
\hline Corynebacterium bovis 1810 & $<0.78$ & Candida $\mathrm{Yu}-1200$ & $>100$ \\
\hline Escherichia coli NIHJ & $>100$ & Candida krusei F-5 & $>100$ \\
\hline E. coli $\mathrm{K}-12$ & $>100$ & Saccharomyces cerevisiae F-7 & $>100$ \\
\hline E. coli $\mathrm{K}-12 \mathrm{ML} 1629$ & $>100$ & Cryptococcus neoformans $\mathrm{F}-10$ & $>100$ \\
\hline E. coli BEM11 & $>100$ & Cochliobolus miyabeanus & $>100$ \\
\hline E. coli $\mathrm{BE} 1121$ & $>100$ & Pyricularia oryzae & $>100$ \\
\hline E. coli $\mathrm{BE} 1186$ & $>100$ & Pellicularia sasakii & $>100$ \\
\hline Shigella dysenteriae JS1 1910 & $>100$ & Xanthomonas citri & $>100$ \\
\hline S. flexneri 4b IS11811 & $>100$ & $X$. oryzae & $>100$ \\
\hline S. sonnei JS1 1746 & $>100$ & Aspergillus niger F-16 & $>100$ \\
\hline Salmonella typhi $\mathrm{T}-63$ & $>100$ & Trichophyton asteroides 429 & $>100$ \\
\hline S. enteritidis 1891 & $>100$ & T. mentagrophytes $\mathrm{F}-15$ (833) & $>100$ \\
\hline
\end{tabular}


shown in Table 8 , dethymicin at 12.5 to $50 \mathrm{mg} / \mathrm{kg}$ strongly suppressed the DTH response.

\section{Rat Skin Allograft}

Tail skins prepared from WKY rats were transplanted to the back of Fisher F344 rats as recipients using the method previously described ${ }^{9}$. Drug was given ip from 1 day after the transplantation daily for 9 days. Results are shown in Table 9. Dethymicin at doses of $5 \sim 20 \mathrm{mg} / \mathrm{kg}$ significantly prolonged survival days of skin graft.

\section{Antimicrobial Activity and Cytotoxicity-}

Antimicrobial activity of dethymicin was examined by serial agar dilution method using MuellerHinton agar (Difco) for antibacterial test which was incubated at $37^{\circ} \mathrm{C}$ for 18 hours and a nutrient agar containing $1 \%$ glucose for antifungal test which was incubated at $27^{\circ} \mathrm{C}$ for 42 hours. Minimum inhibitory concentration (MIC) value is expressed as the minimum concentration which inhibits growth of the microorganisms. As shown in Table 10, dethymicin showed antibacterial activity only against Grampositive bacteria but not against fungi.

Cytotoxicity of dethymicin on tumor cells cultured in RPMI1640 supplemented with 10\% FCS for 48 hours was determined by MTT assay. As shown in Table 11, it inhibited growth of these tumor cells at $7.7 \sim 14.2 \mu \mathrm{g} / \mathrm{ml}$.

The $\mathrm{LD}_{50}$ of dethymicin was found to be more than $400 \mathrm{mg} / \mathrm{kg}$ ip to ICR mice.

\section{Discussion}

In order to find specific and low toxic immunosuppressants, we have searched for inhibitors of MLCR produced by microorganisms and found dethymicin in the mycelium of a strain of Amycolatopsis.

Immunosuppressants produced by microorganisms, cyclosporine $\mathrm{A}(\mathrm{Cy} \mathrm{A})^{10)}, \mathrm{FK} 506(\mathrm{FK})^{11,12)}$ and rapamycin ( $\mathrm{RPM})^{13,14)}$ are well known. Cy $\mathrm{A}$, a fungal metabolite, is a macrocyclic peptide and $\mathrm{FK}$ and RPM, metabolites of Streptomyces, are structurally related macrocyclic lactones exhibiting antifungal activities. Although dethymicin was found as an immunosuppressant produced by a microorganism, it has no antifungal activity and the physico-chemical properties (Table 5) and antimicrobial activities (Table 10) of dethymicin are entirely different from those of Cy A, FK and RPM ${ }^{15,16)}$.

On the inhibitory effect against lectin-induced proliferation of lymphocytes, the relative $\mathrm{IC}_{50}$ of dethymicin was stronger on Con A-induced proliferation than on that induced by LPS. It suppressed DTH response but not antibody formation to SRBC in mice. In conjunction with $\mathrm{T}$ cell-mediated events, dethymicin was effective in prolonging skin allograft in rats.

Results suggest that dethymicin suppressed $\mathrm{T}$ cell-mediated immune responses although it does not inhibit antibody formation to SRBC a T-dependent antigen in mice. Thus, it may inhibit generation of effector T cells. Dethymicin may be useful for organ transplantation and the treatment of autoimmune diseases.

The structure elucidation and mechanisms of action of dethymicin are now under study.

\section{Acknowledgment}

This work was supported in part by a Grant-in-Aid for Cancer Research from the Ministry of Education, Science and Culture, Japan. 


\section{References}

1) Shirling, E. B. \& D. Gottlieb: Methods for characterization of Streptomyces species. Int. J. Syst. Bacteriol. 16: $313 \sim 340,1966$

2) Gordon, R. E.; D. A. Barnett, J. E. Handerhan \& C. H. PAng: Nocardia coeliaca, Nocardia autotrophica, and the Nocardin strain. Int. J. Syst. Bacteriol. 24: 54 63, 1974

3) Pridham, T. G. \& D. GotTlieB: The utilization of carbon compounds by some Actinomycetales as an aid for species determination. J. Bacteriology 56: 107 114, 1948

4) Lechevalier, M. P. \& H. Lechevalier: Chemical methods as criteria for the separation of nocardiae and other actinomycetes. Biology of the Actinomycetes and Related Organism 11: 78 92, 1976

5) Minnikin, D. E.; P. V. Patel, L. Alshamaony \& M. Goodfellow: Polar lipid composition in the classification of Nocardia and related bacteria. Int. J. Syst. Bacteriology 27: 104 117, 1977

6) SuzuKi, K. \& K. Komagata: Taxonomic significance of cellular fatty acid composition in some coryneform bacteria. Int. J. Syst. Bacteriology 33: 188 200, 1983

7) Lechevalier, M. P.; H. Prauser, D. P. Labeda \& J. S. Ruan: Two new genera of Nocardioform Actinomycetes: Amycolata gen. nov. and Amycolatopsis gen. nov. Int. J. Syst. Bacteriology 36: $29 \sim 37,1986$

8) Ishizuka, M.; H. Innma, T. Takeuchi \& H. Umezawa: Effect of diketocoriolin B on antibody formation. J. Antibiotics 25: $320 \sim 321,1972$

9) Masuda, T.; S. Mizutani, M. Injma, H. Odai, H. Suda, M. Ishizuka, T. Takeuchi \& H. Umezawa: Immunosuppressive activity of 15-deoxyspergualin and its effect on skin allografts in rats. J. Antibiotics 40: $1612 \sim 1618,1987$

10) Borel, J. F.; C. Feurer, C. MagñeE \& H. StÄhelin: Effects of new anti-lymphocytic peptide cyclosporin A in animals. Immunology 32: $1017 \sim 1025,1977$

11) Kino, T; H. Hatanaka, M. Hashimoto, M. Nishiyama, T. Goto, M. Okuhara, M. Kohsaka, H. Aoki \& H. ImANAKA: FK-506, a novel immunosuppressant isolated from a Streptomyces. I. Fermentation, isolation, and physico-chemical and biological characteristics. J. Antibiotics 40: 1249 1255, 1987

12) Kino, T.; H. Hatanaka, S. Miyata, N. Inamura, M. Nishiyama, T. Yajima, T. Goto, M. Okuhara, M. KohSAKA, H. AoKI \& T. OChIAI: FK-506, a novel immunosuppressant isolated from a Streptomyces. II. Immunosuppressive effect of FK-506 in vitro. J. Antibiotics 40: 1256 1265, 1987

13) Vézina, C.; A. Kudelski \& S. N. Sehgal: Rapamycin (AY-22,989), a new antifungal antibiotic. I. Taxonomy of the producing streptomycete and isolation of the active principle. J. Antibiotics 28: $721 \sim 726,1975$

14) SeHgal, S. N.; H. BAKER \& C. VÉZina: Rapamycin (AY-22,989), a new antifungal antibiotic. II. Fermentation, isolation and characterization. J. Antibiotics 28: $727 \sim 732,1975$

15) MCAlpine, J. B.; S. J. Swanson, M. JACKSON \& D. N. WhitTERn: Revised NMR assignments for rapamycin. J. Antibiotics 44: $688 \sim 690,1991$

16) Hane, K. M. Fujloka, Y. Namiki, T. Kitagawa, N. Kihara, K. Shimatani \& T. Yadusa: Physicochemical properties of (-)-(1R,9S,12S,13R,14S,17R,18E,21S,23S,24R,25S,27R)-17-allyl-1,14-dihydroxy-12-[(E)2-[(1R,3R,4R)-4-hydroxy-3-methoxycyclohexyl]-1-methylvinyl]-23,25-dimethoxy-13,19,21,27-tet ramethyl-11,28dioxa-4-azatricyclo[22.3.1.0 $0^{4,9}$ ]octacos-18-ene-2,3,10,16-tetrone hydrate (FK-506). Iyakuhin Kenkyu 23: 33 43, 1992 